Павлов Евгений Владимирович

кандидат исторических наук, доцент кафедры теории и истории государства и права

Средне-Волжского института (филиала)

Всероссийского государственного университета юстиции

\section{ОБЫЧНОЕ ПРАВО КАК РЕГУЛЯТОР СЕМЕЙНО-БРАЧНЫХ ОТНОШЕНИЙ МОРДВЫ}

\begin{abstract}
Аннотация:
В статье на основе действовавших у мордвы норм обычного права рассматривается статус членов семейного коллектива, исследуются основные аспекты личных и имущественных взаимоотношений супругов, выяөляются особенности отношений между родителями и детьми.
\end{abstract}

Ключевые слова:

обычай, право, брак, наследование, имущество, община, помолвка, договор, усыновление, семья статус, собственность, мордва.

\section{Pavlov Evgeny Vladimirovich}

PhD in History, Assistant Professor Theory and History of State and Law Subdepartment, Middle-Volga Institute branch of Russian State University of Justice

\section{CUSTOMARY LAW AS A REGULATOR OF MORDVIN FAMILY AND MARITAL RELATIONS}

Summary:

Based on the existing norms of the Mordvin customary law the article reviews the status of family members, researches the key aspects of the personal and property relations of spouses, identifies relations between parents and children.

Keywords:

custom, law, marriage, inheritance, property, community, engagement, contract, adoption, family, status, ownership, the Mordvins.

На протяжении столетий институтом, регламентировавшим повседневную жизнь и деятельность мордовского народа в соответствии с нормами обычного права, была сельская община. Ее основой являлась малая семья, состоявшая из супружеской пары с маленькими или взрослыми неженатыми детьми или без детей. Взаимодействуя с общиной, семья вырабатывала стереотип группового опыта и осуществляла передачу от поколения к поколению этнической специфики и правовых традиций мордвы.

Община существенным образом влияла на семейно-брачные отношения, используя для этого имевшиеся в ее распоряжении способы воздействия, как прямые, так и косвенные. Прямой контроль осуществлялся сельской администрацией, соседями, родственниками и т. д.; косвенный - посредством обычно-правовых норм мордовского народа, выработанных в отдельно взятой общине и руководивших поступками общинников [1, с. 246].

Большое внимание мордовская крестьянская община уделяла нравственному воспитанию детей. В традиционном мировоззрении мордвы отцу и матери отводилась основополагающая роль, порой переходящая в культ. Складывание идеальных образов родителей осуществлялось целенаправленно и составляло часть образа жизни детей. Уважение и почитание родителей являлись базовыми категориями в культуре нравственных ценностей, на их основе выстраивалась вся пирамида нравственных норм и нравственного воспитания. За непочтительное отношение к старшим сход мог наказать виновных. В соответствии с нормами обычного права дети обязаны были повиноваться своим родителям, «поить их и кормить, когда они окажутся в невозможности добывать себе насущный хлеб своими собственными трудами» [2, с. 135]. Дети, отказавшие в помощи престарелым родителям, открыто осуждались обществом.

Родители играли определяющую роль в создании будущей семьи своего ребенка. Вступление в брак без родительского согласия, одобрения или благословения считалось недопустимым. Полагалось, что только родители могут правильно оценить все обстоятельства предстоящей женитьбы своего ребенка, определить, насколько он готов вступить в брак, и выбрать подходящую кандидатуру жениха или невесты.

У мордвы, как и у других народов, существовал обычай ранних браков, когда 5-6-летние дети «бывают уже обручены или засватаны». Ранние браки совершались преимущественно между зажиточными семьями и рассматривались в качестве удачной сделки между родителями. Чувства будущих молодоженов не играли никакой роли. Помолвки малолетних детей не имели не только юридической силы, но и, согласно нормам обычного права мордвы, не считались окончательно решенным делом. До достижения детьми совершеннолетия обстоятельства могли измениться, в связи с чем родители одного из них могли отменить договор. При этом по существовавшим обычаям пострадавшей стороне полагались своеобразные отступные [3, с. 29]. 
Запрещено было вступать в брак с родственниками: родными братьями и сестрами, племянниками, не допускались браки между детьми-побратимами. Среди мордовского народа бытовало мнение о возможности брака между усыновленными и усыновителями, «так как между ними нет крови» [4, с. 25].

Не были исключением смешанные русско-мордовские браки. Каких-либо непреодолимых препятствий здесь не существовало. Ограничения касались прежде всего вероисповедания будущих супругов. Православная церковь считала недопустимым совершение браков между христианами и язычниками, к каковым относилась мордва до ее христианизации. Такой брак был возможен только в том случае, когда один из супругов-иноверцев добровольно менял свое вероисповедание на православие.

Главой мордовской неразделенной семьи являлся большак («покштя», «кудазор»). Домохозяин исполнял функции управления и организации семейного хозяйства, регламентации внутрисемейной жизни, разбора сложных ситуаций внутри семьи, представления интересов семьи во внешних отношениях с миром, законом, властью и церковью. Старший мужчина в доме был блюстителем всего хозяйственного уклада, а его жена - большуха («кудазорава», «покштява») ведала женскими делами. Младшие члены семьи обязаны были слушаться большака и большуху.

У мордвы глава семейства имел право распоряжаться имуществом, но при этом он должен был считаться с интересами всей семьи. В соответствии с существовавшими нормами обычного права никто не мог сместить большака с этой должности, «так как этот поступок был бы равен покушению на священные воззрения и убеждения всего народа» [5, с. 158].

Как правило, смена большака происходила в двух случаях: после его смерти или когда он, чувствуя себя недееспособным, добровольно передавал бразды правления члену семьи по мужской линии. В таком случае остальные родственники обязаны были беспрекословно слушаться нового «кудазора». Если замена главы семьи происходила после его смерти, то нового выбирали на семейном совете. При этом учитывались различные обстоятельства: возраст, семейное положение, способность эффективно вести хозяйство, «а главным образом ...путный ли он человек, ладится ли у него и спорится ли дело и не пьет ли он» [6, с. 175].

В начале XIX в. среди мордвы наблюдается усиление процесса разложения большой патриархальной семьи. В документах, относящихся к этому времени, все чаще начинают фигурировать споры по поводу семейных разделов и дележа имущества, причины которых были различны. Чаще всего они происходили на почве несогласия сына с отцом или на фоне бытовых конфликтов между невесткой и свекровью. Данная проблема существовала с давних времен и не утратила своей актуальности и в наши дни. Молодая семья, проживавшая совместно с родителями или братьями, чаще всего оказывалась в неравном положении по отношению к другим членам семьи. Это проявлялось и в бытовом, и в хозяйственном плане. Молодая невестка («эрвэнэ», «урьва»), пришедшая по мордовскому обычаю в семью мужа, изначально должна была играть роль прислуги, домашней работницы. Об этом свидетельствует и имя, которое давал ей брат ее мужа, - «уряшь» (от «урень» - 'раба'), что явно отражает фрактическое положение, которое занимала молодая женщина в родительской семье своего супруга.

Ее статус в семье менялся только после рождения первого ребенка или появления в доме другой молодой снохи. Но даже после этого молодые женщины не имели юридического права участвовать в семейном совете. При этом замужняя женщина пыталась косвенным образом повысить свой статус посредством влияния на своего мужа. Заметим, довольно часто ей это удавалось. Многие исследователи отмечали, что работящие снохи пользовались в семье большим влиянием. «Уважение к личным правам и сильная привязанность к домашней семейной жизни - вот те нравственные качества, которые проглядываются в действиях мордвы гораздо ярче, чем у других инородцев; женщина как мать и хозяйка дома пользуется большим уважением» [7, с. 136].

Кроме бытовых конфликтов внутри большой семьи существовали хозяйственные причины разделов. Одна из них - отсутствие у молодой семьи собственного имущества, что можно объяснить устойчивостью патриархальных традиций, которые в соответствии с нормами обычного права были направлены на сохранение общесемейной собственности в качестве основы существования крестьянского двора. Правом распоряжаться семейной собственностью наделялся глава семейства - большак. Общим имуществом являлись: полевой и усадебный наделы, дом, постройки, сельскохозяйственные орудия, рабочий скот, домашняя утварь, ульи (борти), денежные средства. Доходы от него шли на содержание всех членов семейного коллектива.

Личной собственностью считались вещи, предметы, полученные в качестве подарка. Обычай дарения был довольно частым явлением, особенно у мордвы-мокши. В основном дарили движимое имущество, причем в рамках семейного коллектива. Традиционно дед завещал младшему внуку свои ульи, а бабка передавала младшей внучке две-три овцы [8, с. 186-188].

В общесемейный фонд большей частью поступали заработки отходников, в то время как самому отходнику доставалась лишь небольшая сумма на личные расходы. Правда, в некоторых случаях мокшане, например, имели право работать лично на себя в свободное время. Как пишет В.Н. Майнов, «ясное дело, тут не всякому члену дозволят личную наживу, но если такой член 
семьи обременен своею собственной семьею, то отец дозволяет ему разные поделки не на прокорм, а на одежду, например, своих детей» [9, с. 138].

Таким образом, в основе имущественных отношений мордвы лежал принцип: все приобретенное на стороне принадлежало всей семье, и пока человек жил в ней, его доход являлся общим достоянием. Исключение составляли только личные вещи невестки, которые хранились в бабьем коробе - парь. Она представляла собой долбленую деревянную емкость, наподобие кадушки, куда складывались праздничная одежда и украшения, некоторые из которых представляли значительную ценность, поскольку при их изготовлении использовались серебряные и золотые монеты. Предметы из пари не могли быть отторгнуты у невестки ни при каких обстоятельствах, они никогда не продавались, а переходили из поколения в поколение. «Бывают, конечно, случаи, что муж заимствует у жены из ее "бабьего добра" кое-что для удовлетворения неотложных домашних потребностей, но все бы соседи расхохотались от души, если бы он дал или жена от него потребовала какой-нибудь документ на занятое имущество» [10, с. 127].

Если каким-то образом парь отчуждалась, то хозяйка имела право востребовать ее обратно или возместить убытки. В Атяшевском волостном суде при рассмотрении дела о продаже мужем Арины Трифоновой 5 золотых монет с мордовского национального головного украшения вопреки ее воле суд принял ее сторону. Ввиду того, что «Арина Трефолева доказала, что те деньги коплены и пришиты ее пробабкой по матери Анною», то приговор был таков: «Пусть обвиняемый уплатит своей жене 75 рублей или же достанет... в Пензе три золотых катериннинских, да 10 крестовых рублевиков серебрянных, а чтобы впредь с чужим добром умел врачаться (обращаться), дать ему 18 розог и арестовать при правлении на два дня, если наказания принять не захочет» [11, с. 128].

На страже женской собственности стояла и община, которая также могла наказать виновного. Если муж кому-то задолжал, но при этом исходил из интересов всей семьи, то жена вместе с ним разделяла бремя долга. В том случае, когда супруг становился должником во имя удовлетворения низменных интересов (пьянство, распутство), то у мордвы-эрзи жена не обязана была платить по долгам. Иное было присуще мордве-мокши, у которой жена стремилась расплатиться за долги мужа. При этом она исходила из того, что обыденное сознание окружавших ее людей осуждало женщину, которая оставалась безучастной к судьбе отца своих детей.

Заботясь о сохранении своего имущества, женщина накануне родов относила парь к своим родителям. В случае смерти жены муж обязан был вернуть парь ее родственникам или отдать ее младшей сестре.

Мордва старались не допускать разделов до тех пор, пока это было возможно. Однако когда это все же случалось, при выделе из отцовской семьи каждой новой семье отводили двор, пашню, сенокосные угодья и другие общинные наделы. Хотя раздел и был внутрисемейным делом, на его проведение в качестве свидетелей приглашались родственники или соседи. При добровольном разделе соблюдался определенный обряд. На стол выставлялись хлеб и соль, зажигалась свеча или лампада, присутствовавшие родственники молились за благополучие нового дома. После моления родители благословляли детей на новое житье иконой: новый хозяин брал ее в руки и вместе с семьей отправлялся в новый дом. Иногда вместе с иконой брали огонь из старого очага [12, с. 14].

При разрешении семейных конфликтов применялись и особые клятвы, в основе которых также лежало божественное санкционирование. Подобно многим другим народам, мордва имела обыкновение «клясться богом солнца»: «Пусть поразит меня Чипаз, если я вру!» [13, р. 174]. С принятием православия мордва стала клясться также на кресте и иконе.

Такое положение дел в области семейно-брачных отношений действовало до начала процесса модернизации, сопровождавшегося массовой урбанизацией, призывом в армию и ассимиляцией мордвы.

\section{Ссылки:}

1. Букин С.М. Национальная государственность мордовского народа: история становления и развития (X-XX вB.). Саранск, 2006. 382 с.

2. Майнов В.Н. Очерки юридического быта мордвы. СПб., 1885. 283 с.

3. Там же. С. 29.

4. Там же. С. 25.

5. Там же. С. 158.

6. Там же. С. 175

7. Мордва. Историко-этнографические очерки. Саранск, 1981.

8. Там же. С. 186-188.

9. Майнов В.Н. Указ. соч. С. 138.

10. Там же. С. 127

11. Там же. С. 128

12. Николаев С.Д. Мордовская семья в середине XIX в. // Крестьянское хозяйство и культура деревни Среднего Поволжья. Йошкар-Ола, 1990

13. Harva U. Die religiosen Vorstellungen der Mordwinen. Helsinki, 1952. 


\section{References:}

Bukin, SM 2006, National statehood of the Mordvin people: the history of formation and development (X-XX centuries), Saransk, 382 p., (in Russian).

Harva, U 1952, Die religiosen Vorstellungen der Mordwinen, Helsinki, (in German).

Mainov, VN 1885, Essays on the legal life of the Mordvins, St. Petersburg, 283 p., (in Russian).

Nikolaev, SD 1990, 'The Mordvin family in the middle of XIX century', Krest'yanskoye khozyaystvo i kul'tura derevni Srednego Povolzh'ya, Yoshkar-Ola, (in Russian).

The Mordvins. Historical and ethnographic essays 1981, Saransk, (in Russian). 